\title{
A hundred years of color studies in insects: with thanks to Karl von Frisch and the workers he inspired
}

\author{
Adrian G. Dyer · Kentaro Arikawa
}

Received: 13 April 2014 / Revised: 14 April 2014 / Accepted: 16 April 2014 / Published online: 3 May 2014

(C) Springer-Verlag Berlin Heidelberg 2014

\begin{abstract}
About 100 years ago it was often thought the world might appear pretty dull for insects until the publication of Karl von Frisch in 1914. This ground breaking study by von Frisch revealed that free flying honeybees could be trained with sucrose solution to visit a colored card, and choose this stimulus correctly in tests when placed amongst a variety of grey cards. The logic of the experiment, done at a time when the spectral sensitivities of bee photoreceptors were unknown, was that if bees were only using an achromatic mechanism to find the conditioned, colored stimulus associated with a sucrose reward then the bees would make mistakes for grey cards having similar brightness values to the colored stimulus. However, the bees reliably chose the colored stimulus amongst many shades of grey (von Frisch 1914), and the eyes of the next generations of researchers were opened to the refinement and diversity of color perception in bees and other insects (Kühn 1927; Daumer 1956; Menzel 1967; Helversen 1972; Giurfa 2004).

This current year of 2014 also marks the 50th anniversary of the first publication of the spectral sensitivities of individual photoreceptor cells in the honeybee by Autrum and von Zwehl (1964), which further helped to establish honeybees as a classic model for research into insect color vision (Peitsch et al. 1992; Briscoe and Chittka 2001).

In this special issue of The Journal of Comparative Physiology A, leading scientists in the field have teamed up to pay tribute to the important start Karl von Frisch gave to the field of neuroethology and insect vision with his publication in 1914. Basic physiology and ecology of bee color vision is summarized by Natalie Hempel de Ibarra
\end{abstract}

A. G. Dyer · K. Arikawa $(\bowtie)$

Sokendai-Hayama (The Graduate University for Advanced

Studies), Hayama, Kanagawa, Japan

e-mail: arikawa@soken.ac.jp and colleagues (Hempel de Ibarra et al. 2014). Lars Chittka and colleagues specifically remind us that whilst bees and other insects see in color, in complex natural environments color perception can be a challenging cue due to the large changes in the spectral quality of light in different foraging environments (Chittka et al. 2014). Anne Leonard and Pavel Masek (2014) discuss the latest evidence that bees can use multimodal information combining both color and olfactory cues to help reduce uncertainty in complex foraging conditions. Indeed there is currently a lot of interest in how bees make decisions in complex environments. Aurore Avarguès-Weber and Martin Giurfa (2014) discuss that a variety of important factors like conditioning method can influence bee perception, possibly through cognitive 'top-down' attention-type mechanisms. Further evidence of complex decision making in bees comes from a nice study on bumblebees by Lisa Evans and Nigel Raine (2014) who show that the way in which some bees make errors may be of adaptive advantage for selecting novel rewarding colors in natural conditions.

Other studies show us that since the time of von Frisch color processing has been tested in a wide variety of different insect species. Motohiro Wakakuwa and colleagues (2014) discuss photoreceptor sensitivity in the leafhopper (Nephotettix cincticeps) which shows some behavioral sensitivity to long wavelength 'infrared' radiation. Francismeire Telles and colleagues (2014) show in the hummingbird hawkmoth (Macroglossum stellatarum) that the behavioral sensitivity to blue wavelength light is much higher than predicted from the retinal photoreceptor sensitivity, which may be related to the innate preference of hawkmoths for blue flowers. Besides bees, flies and butterflies have been well studied. Klaus Lunau (2014) provides a timely review on the color vision of flies which is a system generating a lot of interest at present. Michiyo Kinoshita 
and Kentaro Arikawa (2014) review behavioral studies on the color and polarization vision of the Japanese yellow swallowtail butterfly, Papilio xuthus, again highlighting the importance of the critical von Frisch test. The polarizationbased target discrimination in Papilio also reminds us of the seminal work von Frisch did in this field with honeybees, especially in establishing that honeybees use the pattern of polarized light as a 'celestial compass' to estimate travel direction, and communicate profitable food sources to nest mates through the bees' dance language (von Frisch 1967). Mandayam Srinivasan (2014) provides a comprehensive review on the exciting discoveries that bees can use odometry as a cue to gauge distance, and how the waggle dance of honeybees has been used to decode information about how honeybees are able to perform impressive navigational tasks. The neuronal mechanism underlying the celestial polarotactic compass has been studied most extensively in the desert locust, Schistocerca gregaria, which is here reviewed by Basil el Jundi and colleagues (2014). Antoine Wystrach and colleagues (2014) and Mariel Velez and colleagues (2014) report new evidence that the polarization sensitivity is crucial also for navigation in the Australian desert ant Melophorus bagoti and in the fruitfly Drosophila melanogaster, respectively. Particularly in butterflies, the optical mechanisms underlying the brilliant wing colors, which are viewed and discriminated by their own visual systems, have been extensively studied in recent years, and the beautiful paper by Doekele Stavenga and colleagues (2014) draws our attention to this side of vision science.

Together these studies show us where the research field has come from since the initial breakthrough on honeybee visual processing by von Frisch. They provide a valuable map forward for future work over the coming 100 years. Indeed, as shown by Johannes Spaethe and colleagues (2014) in this issue, the color vision test pioneered by von Frisch still holds important lessons for the testing of other species like stingless bees for which we often lack precise data on receptor sensitivities and behavioral responses to color.

We are most grateful for all the valuable suggestions and helps by Friedrich Barth, Almut Kelber, Johannes Spaethe and Doekele Stavenga as advisors of this special issue. We also send our huge thanks to all colleagues who kindly provided their expertise in the process of reviewing the invited manuscripts.

\section{References}

Autrum H, von Zwehl V (1964) Spektrale Empfindlichkeit einzelner Sehzellen des Bienenauges. Z vergl Physiol 48:357-384

Avarguès-Weber A, Giurfa M (2014) Cognitive components of color vision in honey bees: how conditioning variables modulate color learning and discrimination. J Comp Physiol A. doi:10.1007/ s00359-014-0909-z
Briscoe AD, Chittka L (2001) The evolution of color vision in insects. Annu Rev Entomol 46:471-510

Chittka L, Faruq S, Skorupski P, Werner A (2014) Colour constancy in insects. J Comp Physiol A. doi:10.1007/s00359-014-0897-z

Daumer K (1956) Reizmetrische Untersuchungen des Farbensehens der Bienen. Z vergl Physiol 38:413-478

el Jundi B, Pfeiffer K, Heinze S, Homberg U (2014) Integration of polarization and chromatic cues in the insect sky compass. J Comp Physiol A. doi:10.1007/s00359-014-0890-6

Evans LJ, Raine NE (2014) Foraging errors play a role in resource exploration by bumble bees (Bombus terrrestris). J Comp Physiol A. doi:10.1007/s00359-014-0905-3

Frisch Kv (1914) Der Farbensinn und Formensinn der Biene. Zool Jb Physiol 37:1-238

Frisch Kv (1967) The dance language and orientation of bees. Harvard University Press, Cambridge

Giurfa M (2004) Conditioning procedure and color discrimination in the honeybee Apis mellifera. Naturwissenschaften 91:228-231

Helversen Ov (1972) Zur spektralen Unterschiedsempfindlichkeit der Honigbiene. J Comp Physiol 80:439-472

Hempel de Ibarra N, Vorobyev M, Menzel R (2014) Mechanisms, functions and ecology of colour vision in the honeybee. J Comp Physiol A. doi:10.1007/s00359-014-0915-1

Kinoshita M, Arikawa K (2014) Color and polarization vision in foraging Papilio. J Comp Physiol A. doi:10.1007/ s00359-014-0903-5

Kühn A (1927) Über den Farbensinn der Bienen. Z vergl Physiol 5:762-800

Leonard AS, Masek P (2014) Multisensory integration of colors and scents: insights from bees and flowers. J Comp Physiol A. doi:10.1007/s00359-014-0904-4

Lunau K (2014) Visual ecology of flies with particular reference to colour vision and colour preferences. J Comp Physiol A. doi:10.1007/s00359-014-0895-1

Menzel R (1967) Untersuchungen zum Erlernen von Spektralfarben durch die Honigbiene (Apis mellifica). Z vergl Physiol 56:22-62

Peitsch D, Fietz A, Hertel H, Souza J, Ventura DF, Menzel R (1992) The spectral input systems of hymenopteran insects and their receptor-based color vision. J Comp Physiol A 170:23-40

Spaethe J, Streinzer M, Eckert J, May S, Dyer AG (2014) Behavioral evidence of color vision in free flying stingless bees. J Comp Physiol A. doi:10.1007/s00359-014-0886-2

Srinivasan MV (2014) Going with the flow: a brief history of the study of the honeybee's navigational 'odometer'. J Comp Physiol A. doi:10.1007/s00359-014-0902-6

Stavenga DG, Leertouwer, HL, Wilts BD (2014) The colouration toolkit of the Pipevine Swallowtail butterfly, Battus philenor - thin films, papiliochromes, and melanin. J Comp Physiol A. doi:10.1007/s00359-014-0901-7

Telles FJ, Lind O, Henze MJ, Rodríguez-Gironés MA, Goyret J, Kelber A (2014) Out of the blue: the unexpected spectral sensitivity of hummingbird hawkmoths. J Comp Physiol A. doi:10.1007/ s00359-014-0888-0

Velez MM, Wernet MF, Clark D, Clandinin TR (2014) Walking Drosophila align with the e-vector of linearly polarized light through directed modulation of angular acceleration. J Comp Physiol A. doi:10.1007/s00359-014-0910-6

Wakakuwa M, Stewart F, Matsumoto Y, Matsunaga S, Arikawa K (2014) Physiological basis of phototaxis to near infrared light in Nephotettix cincticeps. J Comp Physiol A. doi:10.1007/ s00359-014-0892-4

Wystrach A, Schwarz S, Schultheiss P, Baniel1 A, Cheng K (2014) Multiple sources of celestial compass information in the central Australian desert ant Melophorus bagoti. J Comp Physiol A. doi:10.1007/s00359-014-0899-x 